from the properties of individual chromosomes but from their unpaired state.

In most plant species the behaviour of univalents is nonrandom in the embryo sac mother cell and random in pollen mother cells ${ }^{3,4}$; in Leucopogon juniperintus, however, it is nonrandom in both ${ }^{5}$. During microsporogenesis, at anaphase 1 , all four univalents go to one pole with a frequency of $55.7 \%$ compared with a random expectation of $12.5 \%$. Because there is a cytoplasmic gradient in embryo sac mother cells and it has been deduced that there is a gradient in the pollen mother cells of Leucopogon, it is very likely that non-random behaviour of univalents is in response to a cytoplasmic gradient.

The univalents in $L$. juniperinus are arranged on their small spindles at the poles when the bivalents move on the metaphase plate, so that their response to the cytoplasmic gradient must occur before metaphase. The response to the cytoplasmic gradient determines not only the unequal segregation of univalent chromosomes but also whether the small spindles will be set up at one or other or both poles.

\section{JUDITH H. FORD}

School of Biological Sciences,

Received October 5; revised November 2, 1970.

1 Battaglia, E., Caryologia, 17, 1 (1964).

2 Hughes-Schrader, S., Chromosoma, 3, 257 (1948).

${ }^{3}$ Kayono, K., Mem. Fac. Sci. Kyushu Univ. Ser. E (Biol.), 2, 53 (1956).

4 Ritushauser, A., Heredity, 10, 367 (1956).

3 Smith-White, S., Heredity, 9, 79 (1955).

\section{DDE reduces Medullary Bone Formation in Birds}

DURING the past two decades residues of certain chlorinated hydrocarbons, especially DDT, have caused declines in the populations of various carnivorous birds in the North Temperate Zone by reducing their reproductive success ${ }^{1-3}$. Contaminated birds lay eggs with abnormally thin, insufficiently calcified shells, so that there is increased egg breakage and embryonic death ${ }^{4-9}$. Although adult mortality, abnormal behaviour, delayed ovulation and nesting, egg eating, and failure to lay eggs also sometimes result from such contamination ${ }^{1-3,8-11}$, the thin eggshell phenomenon is the chief cause of the declines in population ${ }^{3,6,8}$.

Chlorinated hydrocarbons induce hepatic microsomal enzymes that hydroxylate steroids ${ }^{12,13}$, including oestrogens, which are produced in increased amounts by the avian ovary before egg laying. In birds of both sexes, oestrogens mediate deposition of calcium in the medullaries, or hollow parts of the skeleton ${ }^{14}$, where it serves as a labile calcium source for eggshell formation. Chlorinated hydrocarbons should therefore reduce medullary bone formation as well as eggshell calcification. We have investigated this possibility by injecting an oestrogen into male pigeons and determining whether the ingestion of chlorinated hydrocarbons by some of these birds reduces medullary bone formation. $p, p^{\prime}$-DDE[1,1-dichloro2,2-bis ( $p$-chlorophenyl)ethylene] was used because it is the most widespread chlorinated hydrocarbon pollutant, and it has a substantial effect on eggshell thickness.

Seven groups, each of four 5 yr old male silver king pigeons, were injected twice weekly with doses of $\beta$-oestradiol ranging from 0.05 to $0.70 \mathrm{mg}$ per day during the spring of 1969 . At each dose, two birds received feed containing 100 p.p.m. of DDE dissolved in corn oil, and two control birds received feed with an equal amount of corn oil. At the end of 4 weeks, all birds were decapitated, and both femurs were removed, calcined at $675^{\circ}$ for $8 \mathrm{~h}$, and weighed. The average combined weight of both femurs of ten other 5 yr old male pigeons of comparable weights given neither oestradiol nor DDE was $0.793 \mathrm{~g}$. This value was subtracted from all femur weights of experimental birds to give the medullary bone weights (Table 1).

Table 1 Femur Medullary Bone Weights

\begin{tabular}{|c|c|c|c|c|}
\hline$\beta$-Oestradiol (mg/day) & \multicolumn{2}{|c|}{$\begin{array}{c}\text { Control birds } \\
(\mathrm{g})\end{array}$} & \multicolumn{2}{|c|}{$\underset{(\mathrm{g})}{\text { DDE birds }}$} \\
\hline 0.05 & 0.284 & 0.393 & 0.213 & 0.139 \\
\hline 0.10 & 0.201 & -0.060 & 0.219 & 0.037 \\
\hline 0.20 & 0.201 & 0.164 & 0.165 & 0.123 \\
\hline 0.30 & 0.227 & 0.409 & 0.120 & 0.110 \\
\hline 0.40 & 0.324 & 0.293 & 0.037 & 0.109 \\
\hline 0.50 & 0.405 & 0.315 & 0.125 & 0.275 \\
\hline 0.70 & 0.444 & 0.355 & 0.264 & 0.126 \\
\hline $\begin{array}{l}\text { Overall mean weights } \\
\text { Expressed in \% }\end{array}$ & \multicolumn{2}{|c|}{$\begin{array}{l}0.283 \mathrm{~g} \\
100 \%\end{array}$} & \multicolumn{2}{|c|}{$\begin{array}{l}0.147 \mathrm{~g} \\
52.1 \%\end{array}$} \\
\hline
\end{tabular}

Medullary bone formation as a function of the dose of oestradiol was inconclusive, but when the data were pooled for the two groups, medullary bone formation by the birds fed DDE was only $52.1 \%$ as much by weight as that in control birds. The difference between the two groups was significant at the 0.01 level according to the Mann-Whitney $U$ test $^{15}$. This finding is consistent with the reduced level of circulating oestradiol found by Peakall and believed to result from induced hepatic hydroxylation'. Enzyme induction would also explain the altered behaviour, failure to lay, and late ovulation and nesting occurring among the carnivorous birds ${ }^{3,9}$. Peakall and Bitman have presented convincing evidence, however, that the thin-shelled eggs are caused primarily by inhibition of carbonic anhydrase, an enzyme required for shell formation in the shell-forming region of the oviduct ${ }^{3,7,9}$. The diminished reproductive success of these birds is therefore explainable by the simultaneous occurrence of enzyme induction in the liver and enzyme inhibition in the oviduct, both resulting from these chlorinated hydrocarbon pollutants.

This work was supported by grants from the US National Science Foundation and the Research Foundation of the State University of New York. We thank Charles E. Taylor for help with statistical analysis.

Mark I. Oestreicher Deborah H. Shuman Charles F. Wurster

Department of Biological Sciences, State University of New York, Stony Brook, New York 11790

Received March 6; revised November 13, 1970.

${ }^{1}$ Hickey, J. J. (edit.), Peregrine Falcon Populations: Their Biology and Decline (University of Wisconsin Press, Madison, 1969).

2 Wurster, C. F., in Chemical Fallout (edit. by Miller, M. W., and Berg, G. G.), 368 (Thomas, Springfield, Illinois, 1969).

3 Peakall, D. B., Sci. Amer., 222, 72 (1970).

4 Ratcliffe, D. A., Nature, 215, 208 (1967)

5 Hickey, J. J., and Anderson, D. W., Science, 162, 271 (1968).

6 Heath, R. G., Spann, J., and Kreitzer, J. F., Nature, 224, 47 (1969).

${ }^{7}$ Bitman, J., Cecil, H. C., and Fries, G. F., Science, 168, 594 (1970).

Porter, R. D., and Wiemeyer, S. N., Science, 165, 199 (1969).

9 Peakall, D. B., Science, 168, 592 (1970).

10 Keith, J. A., J, Appl. Ecol., 3 (Suppl.), 57 (1966).

11 Jefferies, D. J., Ibis, 109, 266 (1967).

12 Peakall, D. B., Nature, 216, 505 (1967).

13 Risebrough, R. W., Rieche, P., Peakall, D. B., Herman, S. G., and Kirven, M. N., Nature, 220, 1098 (1968).

14. Simkiss, K., Calcium in Reproductive Physiology (Reinhold, New York, 1967).

15 Siegel, S., Nonparametric Statistics, 116 (McGraw-Hill, New York, 1956). 